Research.

\title{
QUALITY OF ANC TREATMENT AND CLIENTS SATISFACTION AT BPM Hj. ELSYE AGUSTIN
}

\author{
Endah Nurmahmudah and $\mathrm{Hj}$. Heni Hendarsah \\ Universitas Muhammadiyah, Tasikmalaya
}

Received: February 13, 2018; Accepted: April 22, 2018; Published: June 30, 2018

To cite this article: Endah Nurmahmudah, Quality of ANC Treatment and Clients Satisfaction at BPM Hj. Elsye Agustin, The Management Journal of BINANIAGA, Vol. 03, No. 01, June 2018, pp. 23 - 34.

Abstract. Rapid development of global worldwide has been happening on technology, information, science and health technology including reproduction health have impacted on a very tight competition in Health Sector. Recently, the society has required quality of service, safety, comfortable and reasonable price. That is why a midwife is requested to be ready and able to respond quickly and anticipate modernization and satisfy the customers. This research aims to figure out the correlation of the quality of antenatal care (ANC) treatment and the level of clients' satisfaction at BPM Hj. Elsye Agustin in Tasikmalaya. Data sampling technique has applied total sampling with cross sectional approach method. And data collection is primary data. Primary data is the data taken directly from the respondents which has been done by the researcher itself. Based on the result of the research, the quality of ANC treatment at BPM Hj. Elsye Agustin is good (66.3\%), it explains that ANC treatment has oriented to the pregnancy needs. Pregnant women who have received pregnancy treatment at BPM Hj. Elsye Agustin are satisfied (71.4\%) indicating that the expectation of pregnant women to get a satisfied treatment has been fulfilled. The correlation of the quality of $A N C$ treatment and the clients satisfaction at $B P M H j$. Elsye Agustin has identified $p$-value of 0.000 indicating that the clients/pregnant women are satisfied with ANC treament.

Keywords: quality, antenatal care treatment, customers'satisfaction.

\section{INTRODUCTION}

Customer service improvement is a crucial issue in management either in government sector or private one. It has happened since customer's requirement against the improvement of service quality from time to time has been increased, but, on the other hand customer service practice has not yet been improved significantly.

Based on the Survey of Demography and Health in Indonesia (SDKI), numbers of mothers who died (AKI) in 2012 was 359 / 100.000 birth of life and it is still far away from MDG target(Millenium Development Goals) in 2015 which is 102 / 100.000 birth of life, so that it is still required hardworking of all components to reach the target. Meanwhile, numbers of baby who died (AKB) in 2012 was 32/1000 birth of life. And the target of AKB in 2015 is 24 / 1000 birth of life (Kemenkes RI, 2015 / the Ministry of Health of the Republic Indonesia).

AKI (numbers of mother who died) and AKB (numbers of baby who died) in West Java is still quite big comparing to other provinces in Indonesia. Eventhough, recently AKI has been decreasing from 651 cases in 2014 to 227 cases in 2015. And AKB has decreased from 2952 cases in 2014 to 992 cases in 2015 (KemKes RI, 2015 / the Ministry of Health of Republic Indonesia). 
Varied factors related to the risk of pregnancy complication and how to avoid it have been identified, however the numbers of mothers who died and babies who died are still quite big. According to Mufdhilah (2009) the reasons why numbers of mothers and babies who died due to lack of mother's knowledge and they have not checked-up their antenatal care periodically.

Antenatal case is the service or treatment given to pregnant woman periodically in order to take care of mother and baby health which is in accordance with minimal standard of antenatal care treatment, such as; weighing the weight, measuring the height, checking blood pressure, giving TT immunitation, measuring the size of uterium fundus, providing consultation, giving Fe tablet. Nevertheless, checking and controlling pregnant woman is to give a quality of antenatal care and early detection of pregnancy complication (Mufdhilah, 2009).

Referring to Zeithaml and M. T. Bitner (1996), there are five dimensions of service quality that have to be concentrated which is as follows; reliability, responsiveness, assurance and empathy. They are crucial factor to define customer satisfaction since the customer will be comparing between actual job performance and their expectation.

Patients satisfaction is subjective matter, it is very hard to measure since it has been changing all the time, and lots of factors as much dimensions of human life have been influencing it. Subjectivity of the patients can be reduced and can be changed to be objective one if many people are having the same opinion about something. However, in order to study the patients satisfaction, valid instruments and good research method should have to be applied (Suryawati, 2004).

$\mathrm{BPM} \mathrm{Hj}$. Elsye Agustin is a BPM having a lot of patients which is 103 clients who are visiting ANC treatment per month. They are not only coming from local village but also from other villages or subdistricts. It has happened due to good promotion by giving quality of the service to the clients. BPM has been operating since 1992 and has been developing its business and working together with some companies which are producing milk for pregnant women such as PT MIROTA KSM producer of Lactona and PT Sanghiang Perkasa (Kalbe Farma group) producer of Prenagen.

\section{A. Quality}

\section{LIBRARY REVIEW}

Quality is a dynamic condition related to product, service, man, process and environment which is meeting or over the expectation. Quality according to Philip Kotler, quality is an integrated characteristics of the product or service that have been influencing their capability to satisfy the customer's requirement either explicitly or implicitly (Vincent Gaspersz, 2011)

Factors influencing the quality of service according to Engeenderhealth mentioned on Syafrudin (2010):

1. Commitment of Health Authorized (midwife).

2. Accomplishment of midwife requirement to supervive the facility.

3. Management, information, training and development 'polindes' (village policlinics)

4. Fulfillment of materials, equipments and tools, and infrastructure.

5. Fulfillment of pregnant woman rights to get the information regarding expected treatment for pregnant woman, as follows:

a. Safety and Comfortable zone of the service.

b. The prior service of privacy and confidentiality.

c. Politeness, friendly and comfortable of the service.

d. It is free to disclose the problem and to give an opinion.

e. Having the Rights to get a continuous treatment. 


\section{B. Antenatal Care Treatment (ANC)}

Antenatal care is a treatment provided to pregnant woman periodically to maintain health of the mother and her baby. Antenatal care is covering pregnancy check-up, problem solving efforts basically upon a deviation and an intervention happened. (Depkes, RI, 1997 / Department Health of the Republic of Indonesia, 1997)

\section{Standard of Antenatal Care Treatment (ANC)}

Antenatal care treatment has to be done $5 \mathrm{~T}$ minimum, upgraded to $7 \mathrm{~T}$ and now it is $12 \mathrm{~T}$, but for thyroid and endemic malaria area is $14 \mathrm{~T}$ :

a. Measure the height / weight.

b. Chek blood pressure.

c. Measure the size of uterium fundus.

d. Give TT immunitation.

e. Give Fe tablet (90 tablets minimum) during the pregnancy.

f. Test sexual contagious diseases / VDRL.

g. Consultation / councelling.

h. Hb test.

i. Urine / protein test.

j. Urine reduction test.

k. Breast control (press and massage the breast).

I. Fit control (pregnancy work out).

m. Therapy of yodium capsule (specific thyroid endemic area).

$\mathrm{n}$. Therapy of malaria medicated.

\section{Antenatal Care Check-Up and Control}

A Midwife will give at least 4 times of antenatal care :
a. One treatment given at the first trimester (pregnancy of 0-13 weeks).
b. One treatment given at the second trimester (pregnancy of 14-27 weeks).
c. Two treatments given at the third trimester (pregnancy of $28-40$ weeks).

\section{Clients Satisfaction}

Satisfaction is the level of someone' feeling or people feeling after comparing the actual service received with an expected one. If the service received is just the same or more than expected, a satisfaction is coming up. Nevertheless, a disappointed feeling would come due to the service which is not meeting their expectation (Pohan, 2002).

The patients / society have considered health treatment is within good quality if it is meeting the requirement and is conducted politely, on time, respect and is able to cure the sickness and to prevent the sickness development. Opinion of the people/society is very important since the patients who are satisfied will absolutely follow the instruction and will repeat their visit. Dimension of quality service of health which is related to the patients'satisfaction will be affecting people health and people wealth. Patients / people have often considered that the dimensions of efficacy, access, interpersonal relationship, continuity and comfortness are the most important one of the quality of health treatment (Pohan, 2002)

\section{Measuring The Satisfaction}

Patients satisfaction is a subjective matter and it is hard to measure since it is changing all the time, however, many factors have been influencing patients'satisfaction as much as the dimensions of people life. Such subjectivity can be decreased or can be changed to be a objective matter if a lot of people are having the same opinion about it. Nevertheless, in order to study patients' satisfaction, a valid instrument of the research and good method have to be applied (Suryawati, 2004).

Endah Nurmahmudah and Heni Hendarsah: Quality of ANC Treatment and Clients Satisfaction at BPM Hj. Elsye Agustin 
According to Parasuraman mentioned on Wiyono (1999) there are 10 indicators to measure the patients satisfactory. However, getting along with further development of the research, the ten factors have been summarized to 5 (five) dimensions of quality of the service as indicators of the service quality:

1. Tangible evidence which is all the things can be seen such as: facility, equipment and tools, comfortable spaces, and officers attitude.

2. Reliability which is the elements related to the ability of providing the reliable services.

3. Responsiveness effort which is the element related to the availability of employees helping and giving the best services for the patients, the persons in charge can give a clear information, they provide rapid and on time services and they give good services.

4. Assurance which is specifically consisting of knowledge, ability, politeness and trustworthy of the persons in charge of, and safety during the treament is important too.

5. Empathy is personal attitude to understant the patients need.

According to Kotler in Nursalam (2011), there are several ways to measure the customers' satisfaction, such as:

1. Complaint handling and suggestion system

2. Survey of the customers satisfaction

3. Ghost buyer

4. Analysis of losing customers

\section{Correlation Between Satisfaction, Expectation and Perception of The Patients}

According to Satrianegara, et. Al. (2009), Satisfaction of health care will be described thru the following matters:

1. Mouth to Mouth Communication

The information received by the patients or society whether it is a satisfaction service or not will be the usefull information as the reference to use or to select such health care service.

2. Personal Requirement

Patients or societies have been always requiring available health care for personal requirement which is available at any convenient time and place complying with their need. They are expecting to get an easy good health care at a normal moment or an emergency one.

3. Previous Experiences

Patients or society who have ever received a satisfactory health care will surely be back to it to get satisfied health care which is in line with their need based on their previous experience.

4. External Communication

Wider socialization of health care system regarding facility, human resources, and superiority things belong to a health care institution will affect the service received by the patients or society.

\section{RESEARCH METHOD}

Type of this research is correlational quantitative method by applying cross sectional approach which is the research has been studying dynamic correlation of inter risk factors with its effects thru the approach of observation or data collection entirely at point time approach.

Type of the data being collected is Primary data. Primary data is the data taken directly from the respondents, its collection has been done by the researcher itself. 


\section{A. Location of The Research}

The research will be done at BPM Hj. Elsye Agustin in Tasikmalaya.

\section{B. Population and Sample}

Population of this research is pregnant women visiting BPM Hj. Elsye Agustin in Tasikmalaya. Sample of the research is all pregnant women having ANC check-up in April 2017 at BPM Hj. Elsye Agustin in Tasikmalaya. Sampling technique that is applied by this research is total sampling. Total sampling is sampling technique where total of the sample is the same with population which is pregnant women who have been checking up their pregnancy at BPM Hj. Elsye Agustin.

\section{Variables of The Research}

Variable is a symptom that is the focus of research. This research is having two variables, quality of ANC treatment as independent variable and Clients satisfaction as dependent variable.

\section{Data Collection Equipment}

\section{Validity Test}

Validity is a measurement indicating validity levels or validity of an instrument (Arikunto, 2006). Validity test has been applied to test the validity of a statement in measuring the instrument. Validity test that has been used is product moment correlation with the following equation:

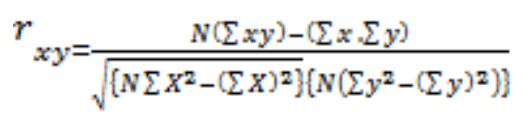

\section{Description}

$r_{x y}=$ Correlation coefficient of variable $\mathrm{x}$ and $\mathrm{y}$

$X=$ Score of the response of each item.

$\mathrm{Y}=$ Total score

$\mathrm{N}=$ Number of the subjects

A question is valid if $r_{\text {count }} \geq r_{\text {table }}$

\section{Reliability Test}

Reliability is an instrument that is significantly reliable to be used as data collection tools since it is a good instrument (Arikunto, 2006). So that reliability is related to the ability of measurement tool measuring the instrument. Reliability test applied is Alpha Cronbach, and the equation is as follows;

$r_{11}=\left(\frac{n}{n-1}\right)\left(1-\frac{\sum s_{i}^{2}}{s_{t}^{2}}\right)$

\section{Description}

$$
\begin{array}{ll}
\mathrm{r}_{11} & =\text { reliability coefficient } \\
\mathrm{n} & =\text { number of items } \\
\Sigma S_{i}{ }^{2} & =\text { total of variant score } \\
S_{t}{ }^{2} & =\text { Variance of total score }
\end{array}
$$

Finding out whether the instrument of the research is reliable or not, it has to be done by comparing the value $r_{11}$ with the value $r_{\text {table. }}$. It is reliable if the value of alpha cronbach $\left(r_{11}\right)$ is higher than $t_{\text {table }}$ value. 


\section{E. Data Analysis}

\section{Univariate Analysis}

Univariate analysis is to get a correlation of frequency distribution and the variables being studied in the previous research.

Each variable is to obtain its mean value, minimum and maximum value of scoring results obtained. Furthermore, it has been categorized based on stated category. The frequency of each category is calculated using the equation below:

$$
P=\frac{F}{N} \times 100 \%
$$

$$
\begin{aligned}
& \text { Description } \\
& \begin{aligned}
P & =\text { Percentage } \\
F & =\text { Frequency at a particular category } \\
N & =\text { Total of sample }
\end{aligned}
\end{aligned}
$$

The percentage quality of ANC treatment has been put in to the standard of the criteria of an object as follows:

$(X)>$ cut of point : Good

$(\mathrm{X}) \leq$ cut of point : Bad

However, analyzing the variable of clients satisfaction has used Likert Scale with the following equation:

T score $=$ the highest value - the lowest value $\frac{{ }_{S}}{y}-\underline{x}$

Description

$X=$ respondent's score on the attitude scale that will be changed to $T$ score

$\underline{X}=$ Mean scores of the group

$\overline{\mathrm{S}}=$ Deviation Standard

In order to identify the category of responsdent satisfaction, mean value of T within group has to be figured out, and the result is as follows;

Respondent is satisfied (+), if T score $>$ mean $T$

Respondent is not satisfied (-), it T score $<$ mean T

(Azwar, 2007)

\section{Bivariate Analysis}

Describing cross tabulation between independent variable and dependent variable, and finding out the correlation between the quality of antenatal care treatment and client satisfaction at BPM Elsye Agustin in Tasikmalaya which is categorized variable (ordinal symptom), then Chi-square equation has to be applied accordingly.

$$
X^{2}=\sum \frac{(f \circ-f h) 2}{f h}
$$

Description

$\mathrm{X}^{2}=$ Chi quadrat

$\mathrm{f}_{\mathrm{h}}=$ Expected Frequency

$f_{0}=$ Frequency is obtained based on the data

In order to define the result of calculation $\alpha=0.05$ which is the acceptance of hyputhesis if $p$ value $\leq 0.05$, it means that statistically it has been proved that a significant correlation between the variables studied in this research has happened. However, if $p$ value $>0.05$, statistically it has not any significant correlation happened between the variables studied. 


\section{RESULT OF ANALYSIS AND DESCRIPTION}

\section{A. Result of the Research}

Based on the Result of treatment quality and pregnant woman satisfaction refers to ANC treatment is as follows:

\section{The Quality of ANC Treatment}

Table 1.

Descriptive Statistic of The Quality of Antenatal Care Treatment (ANC) at BPM Hj. Elsya Agustin in Tasikmalaya

\begin{tabular}{|c|c|c|c|c|c|}
\hline $\begin{array}{c}\text { Score of } \\
\text { service/treatment } \\
\text { quality }\end{array}$ & $\mathbf{N}$ & Min & Max & Mean & S.D \\
\cline { 2 - 6 } & 98 & 15 & 24 & 19.98 & 2.45 \\
\hline
\end{tabular}

Based on the data on table 1, it is indicating the lowest quality score of ANC treatment at BPM Hj. Elsye Agustin is 15 and the highest one is 24. Mean score of quality of ANC treatment is 19.98 with deviation standard of 2.45. Furthermore, categorizing of service quality based on the data distribution (normal) are as follows:

Table 2.

Frequency Distribution of The Quality of Antenatal Care Treatment (ANC) at BPM Hj. Elsya Agustin in Tasikmalaya

\begin{tabular}{|l|c|c|}
\hline \multicolumn{1}{|c|}{ Quality } & Total & Percentage \\
\hline Good & 65 & 66.3 \\
\hline Bad & 33 & 33.7 \\
\hline Total & $\mathbf{9 8}$ & $\mathbf{1 0 0}$ \\
\hline
\end{tabular}

Data 2 has indicated that the respondents have evaluated the quality of ANC treatment given by the midwife at BPM Hj. Elyse Agustin mostly is good which is 65 persons $(66.3 \%)$ and 33 persons $(33.7 \%)$ is bad.

\section{The Satisfactioon of ANC Treatment}

Table 3.

Descriptive Statistic About the Satisfaction of Antenatal Care Treatment (ANC) at BPM $\mathrm{Hj}$. Elsye Agustin in Tasikmalaya

\begin{tabular}{|l|c|c|c|c|c|}
\hline $\begin{array}{l}\text { Score of } \\
\text { Satisfaction }\end{array}$ & $\mathrm{N}$ & Min & Max & Mean & S.D \\
\cline { 2 - 6 } & 98 & 32.00 & 78.00 & 57.88 & 9.39 \\
\hline
\end{tabular}

Referred to the data on table 3 , it has indicated that satisfaction score of pregnant woman upon ANC treatment at BPM Hj. Elsye Agustin is the lowest one of 32 , and the highest one of 78. Mean score of satisfaction of ANC treatment is 57.88 with deviation standard of 9.39. Furthermore, categorizing of the quality of the treatment has been done referring to the data distribution (mean score $\mathrm{T}$ ) which is as follows: 
Table 4.

Frequency Distribution of Antenatal Care (ANC) Treatment Satisfaction at BPM Hj. Elsye Agustin in Tasikmalaya

\begin{tabular}{|l|c|c|}
\hline \multicolumn{1}{|c|}{ Satisfaction } & Total & Percentage \\
\hline Satisfied & 70 & 71.4 \\
\hline Dissatisfied & 28 & 28.6 \\
\hline Total & $\mathbf{9 8}$ & $\mathbf{1 0 0}$ \\
\hline
\end{tabular}

Data on table 4 has indicated that majority of the respondent satisfaction is within satisfied category which is 70 persons $(71.4 \%)$, but dissatisfied category is 28 persons $(28.6 \%)$

\section{Correlation of the quality of ANC treatment and the Satisfaction}

Table 5.

Correlation of The Quality of ANC Treatment and The Clients'satisfaction at BPM Hj. Elsye Agustin in Tasikmalaya

\begin{tabular}{|c|c|c|c|c|c|c|c|c|}
\hline \multirow{3}{*}{$\begin{array}{c}\text { Treatment } \\
\text { Quality }\end{array}$} & \multicolumn{4}{|c|}{ Satisfaction } & \multirow{2}{*}{\multicolumn{2}{|c|}{ Total }} & \multirow{3}{*}{$\begin{array}{c}P \\
\text { value }\end{array}$} & \multirow{3}{*}{ OR } \\
\hline & \multicolumn{2}{|c|}{ Satisfied } & \multicolumn{2}{|c|}{ Dissatisfied } & & & & \\
\hline & $\mathbf{F}$ & $\%$ & $\mathbf{F}$ & $\%$ & $\mathrm{JmI}$ & $(\%)$ & & \\
\hline Good & 56 & 86.2 & 9 & 13.8 & 65 & 100 & \multirow{2}{*}{0.000} & \multirow[t]{2}{*}{8,44} \\
\hline Bad & 14 & 42.4 & 19 & 57.6 & 33 & 100 & & \\
\hline Total & 70 & 71.4 & 28 & 28.6 & 98 & 100 & & \\
\hline
\end{tabular}

Data on table 5 has indicated that respondents who have been evaluating midwives quality in ANC treatment are 56 persons (86.2\%) and they are satisfied, but 9 persons (13.8\%) are dissatisfied. The respondents who are evaluating the quality of ANC treatment are 19 persons $(57.6 \%)$ respondents and they are not satisfied, but 14 persons (42.4\%) are satisfied.

Based on statistical test result using Chi Square, it has obtained $p$ value $0.000<0.05$, it means that there is a correlation between the quality of ANC treatment and the clients'satisfaction at BPM Hj. Elsye Agustin in Tasikmalaya. Pregnant women who have been evaluating the quality of the treatment has a chance of 8.44 times of satisfaction comparing to the pregnant women who have been evaluating bad on the ANC treatment.

\section{B. Description}

\section{Quality of The Treatment}

Based on the result of the research regarding midwives service quality in ANC treatment, the respondents have given it $66.3 \%$ which is good. Referred to the questionnaires distributed to pregnant women who have been doing pregnancy check-up at BPM Hj. Elsye Agustin resulting 15 which is the lowest one and 24 is the highest one. Mean score of the quality of ANC treatment is 19.98. Based on the related data, mostly pregnant women have replied the service given by midwives are good.

As a matter of fact, the questions about pregnancy check-up instrument in the pregnancy room, condition of the room to check-up pregnant women, nurses and midwives performance are good. Furthermore, pregnant women have said that waiting time for examination is not too long as well as pictures about pregnancy and birth of a baby in the waiting room, easy way to contact the midwive when needed, rapidity of helping pregnant women, information given by 
midwives about pregnant women problems and availability of midwives to communicate with pregnant women are good.

According to Irawan (2004) as the healthcare practitioners, the quality of healthcare treatment given by them is very important since good service quality will be building up people trustworthy, patiens retention who have used their treatment.

As the references, previous research done by Nuryanti (2011) at RB Buah Hati Kedungmundu Semarang has found out that 34 samples of the research, mostly midwives communication with the patients is $57 \%$ good. This condition has indicated that mostly respondents have said that midwives are having good communication skill to handle patients'problem which is they have patients oriented.

Based on the description above, the researcher has assumed that it is in compliance with the patients'expectation and the midwives treatment on ANC treatment that could speed up the service. In this case, the patients'expectation is that they can explain their problem and a midwife can perceive what they feel. However, midwives' expectation is that they can describe their treatment about pregnant women in ANC treatment.

\section{Pregnant Women Satisfaction}

According to the result of the research about pregnant women satisfaction, it has indicated that pregnant women satisfaction score about ANC treatment at $\mathrm{BPM} \mathrm{Hj}$. Elsye Agustin is the lowest one of 32 and the highest one of 78. Mean score of ANC treatment satisfaction is 57.88. Referred to the related data, it has explained that in general the respondents are satisfied for what they have received regarding their pregnancy examination. In this case, the respondents who are satisfied about ANC treatment is 70 persons (71.4\%), and the ones who are not satisfied is 28 persons (28.6\%)

Referred to the data above, it has indicated that it is in compliance with pregnant women and healthcare practitioners communicating their problems. The attitude of health care people will affect patients' satisfaction, however, passive patients who are only replying the question given by the midwive will make the situation improper.

According to Depkes RI (The Ministry of Health of Republic Indonesia) (2011), health care practitioners as service provider should have had an interest to help people, are able to be good listener and active one, open to the patients'opinion and understand psychological, social and cultural obstacles.

Patients'satisfaction is the impact of feedback given by the midwife, health care people who are paying good and specific attention to the patient which is handling patients'problems and giving clear information. Satisfaction evaluation upon the expectation of pregnant women in ANC treatment is related to the availability of clear procedure about an action to be done and polite attitude to welcome pregnant women. However, the pregnant women will feel it good, so that the perception of satisfaction will be high obviously.

It has been in accordance with Muninjaya theory (2004) defined that a health care taker is a professional person who should have had an ethical decision making skill by concentrating to the patients'complaint and have had an emphaty to them. Caring, expertise and ability of a nurse or nurse feedback to treat the patients can make them feel having been taken care and treated well.

Actual findings have indicated that pregnant women who have been satisfied with the service of ANC treatment have been describing the midwives professionalism. According to Parasuraman (2009) service is considered competent when the ability to provide such a good service is in compliance with the promise offered. And according to the Department of Health of the Republic

Endah Nurmahmudah and Heni Hendarsah: Quality of ANC Treatment and Clients Satisfaction at BPM Hj. Elsye Agustin 
of Indonesia (2011) health care people who are professional will be acting in line with their skills which are supported by their knowledge and experience as well as their high skills and they do not need to execute any trial and error execution without being completed with professionalism knowledge.

Based on the description above, the researcher has got his own opinion that satisfactory can be felt by pregnant women if their trust is met, nevertheless health care people can also meet the expectation of pregnant women. It means that all dimensions of service quality have got significant satisfaction value such as, direct evidence, cognition, competency, empathy and assurance.

3. The Correlation of The Quality Between Widwives Treatment and Pregnant Women upon Antenatal Care Treatment (ANC)

Based on the result of the research, it has indicated that the respondents who have examined the quality of midwives treatment are 56 persons $(86.2 \%)$ satisfied, and 9 persons (13.8\%) dissatisfied. However, the respondents who have evaluated the quality of ANC treatment are 19 persons $(57.6 \%)$ dissatisfied, but 14 persons (42.4\%) satisfied.

Due to the data indicated above, the better the quality of the treatment given to the patients, the most satisfaction of the patients will be, on the contrary, the worst the quality of the treatment given to the patients, the worst dissatisfaction of the patients will be. As described before, ANC treatment orientation has met the patients'expectation which will make them satisfied. Suryani (2011) said also that if the patients are satisfied, they will be loyal to the related midwives which is they have been motivating them to do their pregnancy check-up periodically, but on the top of it, the most satisfied patients will increase the midwives'image accordingly.

The quality of good treatment given to pregnant women is an aspect to make them satisfied. Therefore, midwives are fully aware of the important of the quality of treatment oriented, however, it is required some efforts to meet the expectation of pregnant women absolutely. It has been clarified by the statistical test of $p$ value $0.000<0.05$, it means that there is a correlation happened between the quality of antenatal care treatment (ANC) and the clients'satisfaction at BPM Hj. Elsye Agustin in Tasikmalaya. Pregnant women who have evaluated the quality of the treatment good is 8.44 times comparing with the ones who evaluated the ANC bad.

Based on the result of statistical test above, the researcher has defined that good relationship between midwives and patients related to ANC treatment can meet the rerquirement of both either patient or midwife as well as their expectation and willingness. This achievement will produce the satisfaction one. According to Supranto (2006) the good communication between health care officer and patients' requirement will make the patients satisfied. If there is good communication happened between health care authorized people and the patients, it is in compliance with good communication oriented with the patients.

Alven (2013) said that an effort to meet the customer expectation is that the person in charge of health care should have to give the training to the health care taker, so that they could give the best treatment to the people needed.

This research is not different with previous research done by Nuryana (2011) who has encountered the patients who have been considering the quality of the treatment is good are 15 persons (41.7\%) satisfied with health care treatment given. Her research has obtained $p$ value of 0.015 explaining that there is a correlation between the quality of the health care treatment done by the health care people and the satisfaction of pregnant women at RB Buah Hati Kedungmundu Semarang. 
Therefore, the midwives should have improved their skills continuously in order to be able to give an effective and efficient treatment which is a continuous educational and experiences improvement received in the clinic. According to Sugiarto (2011), index of patients'satisfaction simultaneously with indicators of health care people could give a description about the achievement level and the condition of health care people.

Referring to the description above, the researcher has analyzed that variable of the quality of treatment given by the midwives who are having patients oriented together with some aspects in it can be considered as predictor (independent variable) to predict the variable of patients'satisfaction (dependent variable). Nevertheless, health care treament as fundamental human needs is always changing from time to time. This kind of difference will affect negatively to the long life of midwives existency since the clients will look for another health care institution.

\section{CONCLUSION}

Based on the description and result of the research about the correlation between the quality of Antenantal Care (ANC) treatment and the clients'satisfaction at BPM $\mathrm{Hj}$. Elsye Agustin in Tasikmalaya, the conclusions are as the following:

1. Pregnant women who have evaluated the quality of Antenatal Care (ANC) treatment at BPM Hj. Elsye Agustin are within good category which is $66,3 \%$, it has explained that ANC treatment has been having the pregnant women oriented accordingly.

2. Pregnant women who have checked-up their pregnancy at BPM $\mathrm{Hj}$. Elsye Agustin mostly are satisfied $(71.4 \%)$, it has indicated that the expectation and requirement of pregnant women has been achieved thru good treatment given.

3. There is a correlation between the quality of antenatal care (ANC) treatment and the clients satisfaction at BPM H. Elsye Agustin in Tasikmalah with $p$ value of 0.000 , it has explained that pregnant women are satisfied with ACN treatment given.

\section{SUGGESTIONS}

1. For the purpose of midwives

It is expected that midwives can maintain even improve their ANC treatment skills as well as the patients'satisfaction oriented.

2. For the purpose of Educational Institution

Educational Institution should have developed their students'competency as midwives candidate thru applied concentration subjects so that the students are able to implement the knowledge and sciences they received.

3. For the purpose of pregnant women

Pregnant women are advised to do regular check-up periodically to the midwife. They can disclose their problems or other things they feel to the midwife and can ask all the things they need to know about their pregnancy condition.

4. For the purpose of next research

It is expected to dig more and more about other variables or factors instead of treatment only such as pregnant women characteristics that can affect the patients'satisfaction.

Next researchers are expected to be able to find out either weaknesses or problems coming up during the research period, so that, they could prepare their planning better.

Endah Nurmahmudah and Heni Hendarsah: Quality of ANC Treatment and Clients Satisfaction at BPM Hj. Elsye Agustin 


\section{REFERENCES}

Alven. 2013. Komunikasi interpersonal di posyandu. Interaksi Majalah Informasi dan Referensi Promosi Kesehatan, Edisi 8.

Asri Hidayat, S.SiT., M.Keb, Mufdhilah, S.Pd., S.SiT., M.Sc., 2008, "Catatan kuliah konsep kebidanan plus materi bidan delima", Mitra Cendikia Pres, Yogyakarta.

Azwar, A, 2007, "Sikap manusia : teori dan pengukurannya edisi 2", Pustaka Pelajar, Yogyakarta.

Depkes RI, 2011. Komunikasi efektif buku bantu bidan siaga, Depkes RI, Jakarta

Erna Juliana Simatupang, SKM., 2008, "Manajemen pelayanan kebidanan", Penerbit Buku.

Gasperez. V., 2011, "Total quality management untuk praktisi bisnis \& industri", Vinchristo Publication, Bogor.

Imbalo S. Pohan, MPH., MHA., Dr, 2002, "Jaminan mutu layanan kesehatan, dasar-dasar pengertian dan penerapan”, Buku Kedokteran EGC, Jakarta.

Irawan, (2004). Kepuasan pasien terhadap pelayanan rumah sakit. Akses Tanggal 1 Februari 2016.

M. Fais Satrianegara, Siti Saleha, 2009, "Buku ajar organisasi dan manajemen pelayanan kesehatan serta kebidanan", Salemba Medika, Jakarta.

Mufdhilah, 2009, "Antenatal care focused", Nuha Offset, Yogyakarta.

Muninjaya. (2004). Manajemen kesehatan. Jakarta. http://manajemen. wordpres.com diperoleh tanggal 19 Maret 2016.

Nursalam, 2011, "Manajemen keperawatan (aplikasi dalam praktek keperawatan profesional)"

Siti Nurjanah, 2012, "Pengaruh pelayanan bidan delima terhadap kepuasan klien di wilayah kecamatan Banyumanik Kota Semarang", http://jurnal.unimus.ac.id

Supranto, J. (2011). Pengukuran tingkat kepuasan pelanggan untuk menaikan pangsa pasar.) Rhineka Cipta Jakarta.

Syafrudin, SKM. M.Kes, Taty Rosynawaty, App, Siti Masitoh, Skp. Mkes, 2010, "Manajemen mutu pelayanan kesehatan untuk bidan", Trans Info Media, Jakarta.

Wiyono D. J., 1999, "Manajemen mutu pelayanan kesehatan : teori, strategi dan aplikasi”, (Quality Management of Healthcare Treatment: Theory, Strategy and Application) Universitas Airlangga, Surabaya.

Zeithamal Valerie A. and Mary Jo Bitner, 1996, "Services marketing", The McGraw. Hill Companies Inc., New York.

Endah Nurmahmudah and Heni Hendarsah: Quality of ANC Treatment and Clients Satisfaction at BPM Hj. Elsye Agustin 